\title{
3
}

\section{The Unequal Place of Anthropology in Cross-Disciplinary Research on Environmental Management in the Pacific and What to Do About It}

\author{
Simon Foale
}

\section{Introduction}

As someone with undergraduate training in marine science, but whose core intellectual interests in the relationship between environmental knowledge and marine resource management have pulled me towards anthropology over three or so decades now, I have become frustrated by anthropology's marginalisation in interdisciplinary research on environmental problems. My collaborations with Martha Macintyre, commencing with my PhD research in the mid-1990s, convinced me of the power of ethnographic insights to illuminate fundamental social, cultural and political dimensions of environmental challenges. Simultaneously, our collaboration fired an interest in political ecology that has since expanded considerably. My work with World Wildlife Fund in the Solomon Islands (1999-2001) sharpened my focus on the extent to which environmental science (particularly the sub-discipline of conservation biology) is not 
only concerningly steeped in and shaped by ideology, but also routinely and wantonly oblivious to unequal power/knowledge relations (Clifton \& Foale, 2017; Foale \& Macintyre, 2005; Foale, Dyer \& Kinch, 2016). Subsequent academic positions with anthropologists (The Australian National University), then biologists (James Cook University [JCU]) and anthropologists again (JCU post-2012) have only increased my alarm at the undeserved hegemony of natural scientists within cross-disciplinary projects. Too often, natural scientists reinvent an 'anti-politics machine' (Ferguson, 1990) of reductionist, managerial and deeply neo-colonial 'social science' that studiously ignores much of what anthropology has contributed, and can continue to contribute, to increasingly pressing environmental problems in the Pacific and beyond. This chapter explores the simultaneous appropriation and dumbing-down of social research by contemporary natural scientists, primarily through politically disengaged and often transparently scientistic approaches, which are greatly aided and abetted by the 'metric fixation' (Muller, 2018) of modern universities. I conclude that the only way to combat these politics is through greater collaboration within anthropology and a more strategic approach to publishing, research funding applications and communicating our knowledge to audiences outside the academy.

In this chapter, I critique the system of managerialist politics that sustains the cultural and financial hegemony of a distinct set of Western scientific (i.e. Linnaean/Darwinian/Victorian) values of nature. These values comprise a combination of species-centric intrinsic value and industrial Western aesthetic value (see Foale \& Macintyre, 2005; Foale et al., 2016), which ultimately perpetuates the dominance of reductionist approaches, and the disciplines that favour them, in environmental research and advocacy. Environmental anthropologists have long argued that the values underpinning and legitimising much global conservation work-including neo-colonial interventions in the lives of economically marginalised peoples in the name of biodiversity preservation-are fundamentally socially and politically constructed. Further, these values and politics are increasingly imbricated with the same forms of neoliberal ideology that simultaneously privilege the natural and medical sciences, and marginalise the social sciences and humanities, within the academy. 
I substantiate this argument with case studies of debates and campaigns about nature conservation, particularly the conservation of tropical marine ecosystems (including coral reefs) and fishery management. The first case concerns environmental functionalism and assumptions about a traditional Pacific fisheries conservation ethic; the second concerns coral reef resilience and the exaggeration of the importance of reef-associated fisheries for food security. These cases underscore the failure by transnational biodiversity conservationists to critically reflect on the extent to which their own brand of 'conservation science' is socially constructed and the apparent inability of many, if not most, of the transnational conservation community to engage seriously with global economic inequality.

Not only are the reductionist-managerialist approaches taken by transnational environmentalists misleading in terms of their erasure of culture, history and politics, but some are now being viewed as downright wrong, in terms of the 'natural science' that they draw on. Some salient examples of this include the exaggeration of the food security importance of coral reefs, which are in fact fundamentally unproductive systems, and a tendency to overemphasise the role of overfishing of herbivorous fish as a key threat to coral reefs and their ecosystem services. More problematically, reductionist-managerialist approaches have for a long time failed to engage with drivers of environmental destruction and poverty on a global scale, particularly (but not exclusively) corporate profit-shifting and capital flight. This occurs despite the fact that poverty alleviation has been a mandate for environmentalists via the Integrated Conservation and Development model since the 1990s.

I argue that the kinds of reductionism favoured and funded by the contemporary academy (and lauded by much of the media) routinely waste time and money and frequently lag far behind the thinking of anthropologists. Anthropologists do not habitually work with large quantitative datasets, nor seek to frame their work as 'hard science'. For this reason, in addition to their penchant for focusing on power relations, including within their own institutions and governments, they have been less successful in influencing governments, the media and research funders. Unfortunately, this has rendered anthropologists more vulnerable to the systematic attacks on the humanities and social sciences that have been observed for several decades across the Englishspeaking world. 


\section{On Method and Mismeasurement}

While most anthropologists do not opt for large quantitative surveys, some do, which usually produces very interesting results (see e.g. Burton, 2007; Henrich et al., 2005; Zimmer-Tamakoshi, 2012). However, the majority of ethnographic work involves observation and interviewing of participants, with an emphasis on describing aspects of culture, politics and history that are pertinent to particular questions or fields of inquiry. Since the ascendancy of neoliberal and managerialist ideologies in Englishspeaking universities, this approach has been steadily devalued; instead, more reductionist and ostentatiously quantitative approaches have found favour and funding, including within the social sciences. The sad reality is that when research results are represented numerically, they tend to be perceived as intrinsically more factual and legitimately 'data'-like. Crucially, 'while we are bound to live in an age of measurement, we live in an age of mismeasurement, over-measurement, misleading measurement and counter-productive measurement' (Muller, 2018, p. 3). Qualitative researchers commonly point out that 'not everything that counts can be counted, and not everything that can be counted counts' (popularly but apparently erroneously attributed to Einstein); however, this trend remains unchanged at the time of writing.

Alan Chalmers' brilliant primer on the history and philosophy of science, What is this thing called science (1999), includes an excellent introductory chapter on inductive reasoning and its limitations. Chalmers described just how complex the process of structuring an inquiry based on inductive logic (which underpins a great deal of quantitative, survey-based research) actually is:

So it would seem that it is a mistake to presume that we must first observe the facts about apples before deriving knowledge about them from those facts, because the appropriate facts, formulated as statements, presuppose quite a lot of knowledge about apples. (Chalmers, 1999, p.11)

This philosophical insight goes right to the heart of what I see as highly problematic in the way that reductionist 'social science' is practised by conservation biologists and like-minded 'social scientists' (see e.g. Cinner et al., 2012, Cinner et al., 2016). It is in the framing of the questions to be tested by the production of quantitative data that things seem to, so often, go wrong. 
The most common framing problem in environmental science in the Pacific concerns economic personhood-many studies are based on the assumption that everyone behaves like a 'possessive individual' (Macpherson, 1962; Martin, 2007; Sykes, 2007). Rural coastal economies across the biodiversity-rich parts of the Asia Pacific region are based on the use of natural resources; therefore, economic data is routinely sought in studies focusing on sustainable resource management. Such studies assume that engagements with the environment can be hypothesised by assuming that both individuals and collectives are motivated primarily by a desire to accumulate wealth. Melanesian economic personhood is, in stark contrast to this assumption, strongly oriented around redistribution (Curry et al., 2015; Gregory, 2015) — agricultural surpluses are traditionally shared in a competitive arena (usually at traditional feasts), and those who give the most away tend to achieve increased social status and political power. If all Melanesians were rationally acting, economically self-maximising possessive individuals, there would be no need for Melanesian trade store owners to post notices declaring 'No Credit' (see also Curry, 2005, 1999). We would also observe no sabotaging of fish-aggregating devices (Albert et al., 2014), water supplies, mobile phone towers or airstripsall economically irrational behaviours that are the product of highly competitive and complex political relationships among mostly kin-based social groups, whose economic worldviews depart fundamentally from that of the possessive individual (Bainton \& Macintyre, 2013).

Anthropologists know that economic personhood and behaviour vary dramatically among different cultures, and within cultural groups, and are also constantly changing (Gregory, 1997, 1999, 2015; Sykes, 2007). This knowledge, generated mostly through detailed, long-term ethnographic work, has profound implications for the appropriate design and framing of questions around income expenditure (e.g. how it is consumed, accumulated or redistributed), labour investment (Curry et al., 2015) and discounting behaviour in relation to the impact of current harvesting pressure on the future productivity of a resource (Cohen \& Foale, 2013; Foale et al., 2011). Economic investigations must account for the intersection of market economies with subsistence and ceremonial activities (Bainton \& Macintyre, 2016) and the cultural and political context of complex and often dynamic negotiations over tenure, in addition to individual and collective benefits from both subsistence and commoditised resources (Macintyre \& Foale, 2004, 2007). This canon of deeply socially informed environmental and economic research appears 
to be either unknown or deemed irrelevant by many conservationist researchers who perform large quantitative social surveys investigating environmental conservation and resource management questions with little or no attention to this sort of detail.

In addition to making ungrounded assumptions about human behaviour, transnational conservation biologists and their allies often perceive humans as simply an obstacle to the ultimate goal of saving 'globally important' biodiversity. Biodiversity conservation goals are frequently framed on a scale that encompasses a number of very different cultural groups of people (e.g. the Coral Triangle); therefore, we observe a common inclination to disregard inconvenient cultural complexity when constructing research studies, particularly for projects that are funded by donors whose worldview is shaped primarily by Western environmental ideals.

Researchers with a predilection for quantification and ignorance of (or even contempt for) relevant social theory will count what is easy to count and simply ignore what is not. They will opt for an impressivelooking sample size that may or may not have any useful statistical meaning in relation to parameters that actually matter. Ultimately, such choices are more concerned with the display of 'doing big science' than producing reliable, relevant and useful 'truths'. The current academic system makes this approach, despite extensive published critiques of it (Cannizzo \& Osbaldiston, 2019; Ginsberg, 2011; Muller, 2018), easy to get away with and even easier to sell. Austerity within the academy has also applied significant pressure on researchers to spend less time in the field; this applies pressure to generate data in ways other than participant observation, which requires long periods of getting to know host communities, learning their language and achieving a level of rapport that allows many insights into culture, politics and history that would never be possible with briefer periods of contact.

Managerialism within the academy fosters environmental managerialism. Interdisciplinary journals that concern the environment are predominantly edited by natural scientists, who are typically ignorant of large swathes of social literature relevant to human ecology and cultural institutions pertaining to environmental use and management. An increasingly disturbing problem in this rapidly expanding interdisciplinary arena is that natural science journals tend to have a much 
higher impact factor than purely anthropological or sociological journals. ${ }^{1}$ Most natural scientists, particularly the younger cohorts, are highly likely to judge the worth of a given journal, and the work it showcases, based on its impact factor alone. These same scholars also rarely consult books, including edited books, which continue to communicate a large proportion of anthropological research.

Global-scale crisis narratives, panaceas and 'silver bullets' for environmental management are more likely to find favour with the editors of high-impact journals such as Nature and Science than nuanced, rigorously theorised and painstakingly crafted case studies made in one or a small number of locations. They can also be made more authoritatively with quantitative survey data that not only routinely erases cultural difference and historical or political complexity, but also forces homogenising assumptions about economic behaviour such as possessive individualism or homo economicus. Winning the big prize of a publication in Nature or Science more or less immediately confers rewards such as large research grants and promotion. Therefore, regardless of whether a researcher believes a global-scale approach is one that will be more likely to produce social data that is reliable and closely represents the truth about questions that are the product of theoretically solid research, the incentive to take this approach is significant.

The conservation biology worldview is one in which scientific expertise about a given component of the natural world (be it particular species, such as turtles or tigers, or entire ecosystems, such as coral reefs or rainforests) confers not only a mandate but a right to intervene in the lives of humans anywhere on the planet if they are seen as presenting a proximate threat to the species or ecosystems in question (Dowie, 2011; Fairhead \& Leach, 2000; Fairhead, Leach \& Scoones, 2012). Therefore, publications on human-environment topics with global scope (as represented by work that provides analyses of peoples who are identified primarily in terms of their dependence on or association with a global conservation target such as coral reefs or rainforests) will be more likely to attract the attention of editors of high-impact (and high-prestige) scientific journals. However, the global scope of the work necessarily applies pressure to erase difference and complexity, which means that universalising forms of social science,

1 At the time of writing, Conservation Biology and Ecology and Society have impact factors of 5.89 and 4.55, respectively, and Current Anthropology and American Anthropologist have impact factors of 2.32 and 2.709 , respectively. 
such as behavioural economics or psychology, are more likely to be adopted than anthropology, with its inconvenient focus on diversity. The one standout exception that comes to mind is Joseph Henrich and colleagues' cross-cultural examination of game theory, in which a series of coordinated experiments were run by a large collaborating group of anthropologists across 15 small-scale societies, specifically to demonstrate cross-cultural differences in economic behaviour via the results of playing games such as Ultimatum. The study ultimately convincingly debunked the popular homogenising trope of homo economicus (Henrich et al., 2005).

\section{Case 1: Social-Ecological-Systems Theory as Zombie Neofunctionalism}

Social-Ecological-Systems (SES) 'theory' (Folke et al., 2005; Folke et al., 2002; Walker \& Salt, 2006; Walker et al., 2004) is little more than a reinvention (and rebadging) of the environmental functionalism, also known as neofunctionalism, that dominated environmental anthropology in the 1960s (Lee, 1969; Rappaport, 1968; Vayda, 1961) and had been widely abandoned by most environmental anthropologists by the late $1970 \mathrm{~s}$ and 1980s (Orlove, 1980). Neofunctionalism was an offshoot of structural functionalism and hypothesised that pre-industrial societies evolved many cultural institutions, including religious beliefs, as adaptations to environmental limits. Common examples of such institutions include taboos on harvesting supposedly limited resources (Rappaport, 1968) or various measures for constraining human population growth, including ritual adult suicide and warfare (Firth, 1983).

However, the founders and contemporary adherents of SES thinking have almost never bothered to engage with the large and very impressive body of environmental anthropology literature of the 1950s and 1960s, which explored and tested neofunctionalist theories, much less the extensive critiques and debates (among anthropologists) about neofunctionalism following this period (e.g. Orlove, 1980; Rappaport, 1984; Vayda, 1989). Even Roy Rappaport, in his 1984 reply to critics of the functionalist aspects of his famous book Pigs for the ancestors (1968), argued that his original analysis was 'guided by criticisms of functionalism, rather than functional doctrine per se' (Rappaport, 1984, p. 345). 
Nevertheless, SES thinking and theorising, almost all of which has been conducted by ecologists and economists, has been immensely rewarding for those involved. It powerfully underpinned much of the direction of the Millennium Ecosystem Assessment (many SES heavyweights were part of this lavishly funded project) and remains the core belief system and methodological approach of the Stockholm Resilience Institute-a large, well-funded and prestigious enterprise that researches a wide range of environmental problems on multiple scales.

SES thinking routinely asserts that 'indigenous peoples' pre-historically 'evolved' cultural institutions that allowed them to adapt to the limits of their environment (in the case of my field, customary marine tenure and fishing taboos) and that, where people cannot be observed exhibiting a traditional conservation ethic, this must be due to the corrosive influences of Westernisation (Berkes, 1999; Berkes, Colding \& Folke, 2000; Cinner et al., 2006; Johannes, 1978). While this may well be true for some groups in some parts of the world, it certainly has not been the case anywhere I have worked in the Pacific-several of my publications critique the critical tenets of SES (Foale, 1998a, 2006a; Foale, Wini \& Fernandes, 2017; Foale et al., 2011). Many other (mostly anthropological) studies have produced analogous criticisms of neofunctionalist and/or SES thinking (Bulmer, 1982; Carrier, 1987; Firth, 1965; Lieber, 1994).

Most notably, I possess unpublished data collected in Tikopia in 2010 that supports observations made by Raymond Firth in the 1920s (Firth, 1965). Firth's research showed that, despite Tikopia being one of the most densely populated high islands in the Pacific, and despite having a very tightly managed and highly intensified farming system, Tikopians exercised no proprietary forms of exclusion (marine tenure) or taboos (fishing bans) over their coastal reefs. If we follow SES neofunctionalist logic, if any group of Pacific Islanders should be using extensive and highly elaborated forms of marine tenure and taboos, it would have to be the Tikopians. However, they are not, nor do Tikopians have other traditional regulations that could credibly be counted as having a fisheries management function, such as restrictions on species or fishing gear types (cf. Carrier, 1981).

Neofunctionalist reasoning permits a form of global environmentalist managerialism that shifts the responsibility for environmental management neatly onto economically marginalised people, by appealing to the desirability of preserving ancient cultural heritage as a means of 
justifying the imposition of that load. This is a clever sleight of hand that excuses scientific imperialism in the name of both cultural and biodiversity preservation. The annoying question of whether any of those owners of said cultural heritage might also aspire to a modern lifestyle, which might come at the expense of the sustainability of their natural resources, is quietly sidelined. Neofunctionalist tropes remain wildly popular with wealthy globetrotting conservationists, natural scientists and documentary makers to this day (e.g. Conservation International, 2019). There will always be a market for these ideas, because jaded, conservationminded residents of the urban industrialised global North are clearly comforted by the idea that, somewhere in the world, 'indigenous peoples' are living in harmony with nature.

\section{Case 2: Environmentalism, Values and 'Conservation Science'}

Conservation scientists self-identify as objective thinkers, perceiving themselves to be 'better' at objectivity than anthropologists, who many of them believe inhabit a lower position in the disciplinary pecking order (Rose, 1997). However, there has long existed a small number of dissenters. Senior conservation biologist John Lawton is on record arguing that 'conservation is not a scientific activity' (1997, p. 4). There now exists a large canon of critical political ecology writing, mostly by anthropologists, that documents high-handed, unscientific and socially obtuse environmentalism (Dowie, 2011; Fairhead \& Leach, 1996; Filer, 2004a; Foale \& Macintyre, 2005; West, 2006; West, Igoe \& Brockington, 2006). Despite the volume and power of this work, it appears to have made little impact on policy or practice within the contemporary international conservation arena. The stark reality is that the academic publishing system has made it possible for conservation biologists to ignore completely any and all critique from the social sciences and from within their own ranks (Lawton, 1997; Redford, 1991; Soule, 1985).

Moreover, few conservation biologists reflect very carefully on why or how they value nature, a topic about which anthropologists, in addition to sociologists, historians and geographers, have written a great deal (Cronon, 1996, 1995; Foale \& Macintyre, 2005; Foale et al., 2016; Ingold, 1993, 2000; Milton, 2002, 1993). This is unfortunate; however, it is again possible to see how a lack of curiosity about ontology and epistemology makes it easier to retain one's conviction about a conservation issue- 
contemporary academic and research funding structures do nothing to challenge this lack of curiosity. For example, why are certain species, or groups of species, deemed more deserving of scientific attention and conservation funding than others? Why are coral reefs and rainforests more popular research topics among natural scientists than estuaries or heathlands? The ways in which species and ecosystems are valued have as much to do with their aesthetic qualities (Foale \& Macintyre, 2005), in addition to the 'cumulative intrinsic value' of large species counts (the so-called 'hotspot' logic; for a critique of this, see Foale et al., 2016), as any ostensibly 'scientific' logic. When working in another country with rural people who speak a different language, few conservation scientists even bother to learn the local language names for the fish, plants and other species they seek to protect (Cohen et al., 2014; Foale, 1998b; Hviding, 2005). If they did, they would immediately realise that local ways of valuing nature are almost certainly very different from their own. In this intellectual and managerial context, it is easy to raise research grants for the conservation of 'iconic' species such as turtles, cetaceans and large mammals (particularly if they have big eyes), with little attention given to the construction of those species' value in the minds of both scientists and the public, who often provide the political leverage to ensure continued flows of funding (Foale \& Macintyre, 2005; Foale et al., 2016).

\section{On Epistemological Entitlement-Some Sciences are More Equal than Others}

Given the inequalities within the academic publication and funding systems outlined above, it is impossible to be surprised by the obvious sense of entitlement displayed by academics in some disciplines. The prefixes 'hard' and 'soft' are still code for 'legitimate' and 'flaky', respectively. Apparently, James Watson once said that 'there is only one science, physics; everything else is social work' (Rose, 1997, p. 83). My own long-term interactions with marine scientists at various research institution $s^{2}$ have provided a wealth of participant-observation data that attest to the depth of conviction among natural scientists of their intellectual and epistemological superiority over all brands of social

2 These include JCU, Australian Institute for Marine Science, Commonwealth Scientific and Industrial Research Organisation (CSIRO) and the Great Barrier Reef Marine Park Authority. An anthropologist colleague based at JCU once observed that Townsville probably has the highest density of marine scientists per square kilometre in the world. 
scientists, but most notably those who do not produce large quantitative datasets that can be subject to elaborate and arcane (the more arcane, the more impressive) analyses of variance (for a scathing critique of this behaviour, see Turner, 2019).

However, a far more pernicious problem than disciplinary snobbery and dismissing or completely ignoring academic contributions is the appropriation of ideas that are initially spurned, without due credit. The process is described perfectly by J. B. S. Haldane's (1963) 'four stages of acceptance':

1. This is worthless nonsense.

2. This is an interesting, but perverse, point of view.

3. This is true, but quite unimportant.

4. I always said so.

Below, I consider ideas about the broader political and economic drivers of environmental degradation that have long been a focus of study in anthropology and related disciplines and have now belatedly been appropriated by natural scientists. The first idea is that capital flight via profit-shifting is the most important contemporary driver of inequality and underdevelopment globally; the second is that coral bleaching, not local overfishing, is the pre-eminent threat to coral reefs.

\section{Capital Flight as Primary Contemporary Driver of Inequality and Underdevelopment}

Anthropologists have been writing about inequality for a long time (Beteille, 1969; Dumont, 1970; Fabinyi, Foale, \& Macintyre, 2013; Lawrence, 1964; Macintyre, 1998; Mead, 1956). But it has not been until the relatively recent publication of survey-based approaches (Wilkinson, 2005; Wilkinson \& Pickett, 2009) that inequality as a driver of social ills has attracted widespread treatment in the media (Wike, 2013). ${ }^{3}$ However,

3 Another (perhaps more significant) reason for the upswing in media attention to inequality's role as a driver of social damage is the sheer magnitude of the increase in economic inequality in Englishspeaking countries since the 1970s, in addition to the Global Financial Crisis and numerous recent exposés of financial fraud and corruption. 
many natural scientists appear to remain indifferent to the importance of inequality as a fundamental social problem (Büscher et al., 2017) — this is also the case within university management spheres. ${ }^{4}$

Publications such as Nicholas Shaxson's Treasure islands (2011), the impressive string of exposés produced by the International Consortium of Investigative Journalists (e.g. LuxLeaks and the Panama Papers) and groups such as the Tax Justice Network and Global Financial Integrity have done much to draw attention to the importance of capital flight as a driver of poverty, underdevelopment and environmental degradation around the world, particularly in low-income countries where resource extraction by multinational corporations remains the primary source of revenue. A crucial fact emerging from this investigative work has been that capital flight resulting from trade mis-invoicing and other financial fraud by transnational resource extractors (mostly logging, mining and fishing companies) significantly eclipses inflows of development aid (Global Financial Integrity, 2015, 2017).

Anthropologists, political scientists and political ecologists (and also investigative journalists) have been at the cutting edge of analysis and commentary about the significance of capital flight as a driver of poverty and corruption (Mousseau \& Lau, 2015; Rawlings, 2006, 2011; Sharman, 2008, 2017; Van Fossen, 2012), in addition to pointing out the problems it poses for the SES paradigm that is so central to the worldview of the Resilience Alliance and many conservation biologists (Clifton \& Foale, 2017; Fabinyi, Evans \& Foale, 2014; Foale et al., 2013; Foale et al., 2016). The idea that biodiversity conservation and the associated preservation of ecosystem goods and services can somehow be achieved primarily with local-scale interventions that help 'communities' of homo economicus to comply with a global managerialist template, such as Ostrom's Eight 'Design Principles's (Ostrom, 1990), seems even more

4 A bleakly Orwellian twist on Haldane's abovementioned axiom is the recent announcement by JCU, using a set of global metrics, that it has been judged 'best university in the world in its commitment to the United Nations goal for reducing inequality' (James Cook University, 2019). The fact that JCU's Vice Chancellor earned AUD 982,500 in 2017 (Times Higher Education, 2018), and the disparity in pay between senior management and ordinary employees is already very wide and continuing to widen, clearly has not been factored into these metrics.

5 Ostrom's Eight 'Design Principles' for successful collective management of 'common pool resources' (CPRs) are: 1) Clearly defined boundaries; 2) Congruence between appropriation and provision rules and local conditions; 3) Collective-choice arrangement; 4) Monitoring; 5) Graduated sanctions; 6) Conflict-resolution mechanisms; 7) Minimal recognition (by governments) of rights to organise; and 8) (for CPRs that are part of larger systems) Nested enterprises. 
ludicrous in the context of the immense financial haemorrhaging that has been accelerating over the past half-century or so. However, in keeping with Haldane's observation, the Resilience Alliance have finally seen fit to claim expertise on the issue (Galaz et al., 2018) and it will be interesting to see how this work affects (or not) the transparently functionalist thinking that has dominated the group's outputs since their inception.

\section{Coral Bleaching}

The magnitude of the moral problem posed by coral bleaching (HoeghGuldberg, 1999) has long concerned myself and some of my colleagues (Foale, 2006b; Foale \& Macintyre, 2005; Foale \& Manele, 2004). Despite the immense injustice evident in the fact that coral bleaching is a form of environmental damage that is experienced disproportionately by people in poor tropical countries ${ }^{6}$ but driven primarily by the excessive energy consumption (and associated carbon dioxide emissions) of people in rich countries (and, increasingly, also in Brazil, Russia, India and China), opinion leaders in coral reef science have framed the problem differently. For a long time, they have diluted the importance of bleaching by casting it as just one of 'multiple drivers' of coral reef destruction, along with fishing of herbivorous fish and sediment and nutrient runoff (Hughes \& Connell, 1999; Hughes et al., 2010; Hughes et al., 2003; Hughes et al., 2006; Hughes, Barnes et al., 2017).

Attention to the non-carbon-related drivers of reef damage, particularly fishing and, even more particularly, fishing of herbivorous species such as parrotfishes (family Scaridae) and surgeonfishes (family Acanthuridae), has driven a vast global program of austerity measures (Clifton \& Foale, 2017; Foale et al., 2013), in the form of no-take marine protected areas (MPAs). Environmentalists and marine scientists correctly argue that MPAs, which prohibit fishing within a defined area of sea territory, allow the recovery of fish populations, including the grazing species that some argue prevent overgrowth of corals by macro-algae (more detail on this is given below). Fish population recovery helps to maintain the ecological integrity and functioning of the coral reef ecosystem (Hughes et al., 2006) and eventually also delivers a fishery 'dividend', via the adult fish and fish eggs and larvae that are 'exported' beyond the boundaries of the MPA to areas open to fishing (Russ et al., 2004). The trouble is that most MPA

6 The one clear exception being the Great Barrier Reef in Australia. 
programs have not been accompanied by any effective schemes to offset either the immediate economic costs of exclusion from no-take areas suffered by mostly very poor (and often landless) fishers in low-income countries (Clifton \& Foale, 2017; Fabinyi, 2018) or the global drivers of poverty and inequality (Hickel, 2017; Li, 2010). Despite a long series of critiques by anthropologists and political ecologists of conservation programs that impose local costs for problems that are often primarily driven by global-scale processes (including but not limited to climate change), the natural science literature has continued to focus on local 'solutions'.

The key crisis narrative underpinning the campaign to use MPAs to 'save coral reef biodiversity', by preventing fishing of grazing reef fish species, stems from the paradigm of the coral-algal 'phase shift', an idea that has its origins in work done in the Caribbean (Hughes, 1994; Knowlton, 1992). Here, the irreversible transformation of coral reefs to stands of Sargassum spp. (brown macro-algae) was observed as a consequence of over-harvesting of parrotfishes and other grazing fish species, combined with elevated runoff of nutrients and sediments. It is still possible to find examples of phase-shifted reefs; however, there remain problems with the model, including critiques published by high-profile marine scientists (Bruno, Cote \& Toth, 2019; Bruno et al., 2009; Russ et al., 2015). The coral-Sargassum phase-shift paradigm has also become a central component in the development of 'resilience theory' (Walker \& Salt, 2006), as introduced above. For a long time, the work of the Resilience Alliance has studiously ignored the role of colonialism and global capitalism in driving poverty and environmental destruction in the global economic periphery.

In the wake of the back-to-back bleaching episodes on the Great Barrier Reef in 2015 and 2016, the 'multiple drivers' model now appears to have been discarded (or at least temporarily sidelined) and carbon dioxide has now been pronounced to represent the predominant existential threat to coral reefs (Hughes, Kerry et al., 2017). This necessarily amounts to a paradigmatic shift in the burden of 'blame' for coral reef ecosystem degradation from the local to the global, but it remains to be seen whether this will translate to a slowing or cessation in the imposition of austerity programs on economically marginalised coastal fishers. It is unlikely that we will see much engagement of marine scientists with historical and contemporary drivers of poverty and inequality acting on scales larger than the local; therefore, this highly problematic aspect of the 'multiple drivers' approach may persist. While this change in perspective 
on the importance of bleaching in reef degradation does not amount to a complete appropriation of the longstanding critiques by anthropologists outlined at the start of this section (in line with Haldane's four stages), it does represent a shift in that direction.

\section{The Ascendancy and Dominance of Conservation Biology within the Natural Sciences}

Within marine science, some sub-disciplines have taken a back seat for many years, largely as a consequence of the market dominance of conservation-related paradigms, most notably the branch of ecology linking biodiversity to ecological resilience (Hooper et al., 2005; Mora et al., 2011; Worm et al., 2006) and a related branch of ecological economics relating ecosystem resilience to the delivery of ecological goods and services (Costanza et al., 1997). Research on food webs and nutrient cycling on coral reefs (Johannes et al., 1972) flourished in the 1970s and 1980s and established one of the key (and enduring) paradigms of coral reef ecology, which is that reef corals are remarkably adapted to low-nutrient (read: unproductive) environments. The corollary of this is that coral reefs are lousy producers of that most celebrated of ecosystem services-fish (Birkeland, 1997, 2017). Indeed, the numerous studies that show, from various perspectives and with different types of data, that reef fisheries, while species-rich, can be overharvested very quickly and then take a long time to recover (Russ \& Alcala, 2010) run strongly counter to the many pronouncements about the pivotal importance of coral reefs for the food security of millions of people in the tropics (for a detailed discussion, see Foale et al., 2016).

A comparatively small number of species underpin protein security for the most heavily populated parts of South-East Asia today: these are uncharismatic schooling sardines, scads, mackerels and tunas and a small number of aquacultured species. Coral reef fish account for, at most, approximately one-fifth of the fish produced in the Philippines, based on government fishery data (Clifton \& Foale, 2017) and rural surveys (Dey et al., 2005; Fabinyi, Dressler \& Pido, 2017). These (mostly small) pelagic fish occur in vast numbers in nutrient-rich offshore and coastal waters, largely independent of corals and the biodiversity associated with coral reefs that are so valued by conservationists. Importantly, because 
they are short-lived and fast-growing, they are far more resilient to heavy fishing pressure and, thus, increasingly important for food security, particularly as coastal populations grow. Small (and large) pelagics are also increasingly important for coastal Papua New Guineans and Solomon Islanders (Albert et al., 2014; Foale \& Sullivan, 2013; Roeger, Foale $\&$ Sheaves, 2016). Despite these stark facts about the relatively minor importance of corals and coral reefs for food security, Web of Science searches show that the great majority of published scientific research on fish and fisheries in the Coral Triangle countries focuses on coralassociated species (Clifton \& Foale, 2017).

Clearly, the production of high-status science on coral reefs and their associated fisheries is largely rooted in affluent Western cultural values and ideologies. The exaggeration by conservation biologists of the numbers of people who allegedly depend on reef fisheries for food security is no doubt to help sell the importance of reef conservation programs (principally the implementation of MPAs) to donors. It is a political ploy used because the 'real' reason coral reefs are valued by Western scientists is for their intrinsic (i.e. high species richness) and aesthetic value. The greater focus of scientific publications on fish and fisheries associated with reefs, rather than the small number of uncharismatic but highly productive species (e.g. scads and sardines) that are so important to the lives of poor people in the Asia Pacific region, is simply because conservation scientists are more interested in biodiversity than they are in food security. Technocratic but politically disengaged (or simply disingenuous) research on coral reefs enjoys a larger market and continues to reward researchers with more lucrative grants than the critical approaches taken by most anthropologists and political ecologists.

\section{Conservation without Development is, still, Imperialism}

If we take the ideas of Freire (1973) about the pivotal role of education for critical consciousness seriously, as well as the ideas of Sen (1999) and Nussbaum (2011) about capabilities, then the mandate for adequately funded education and health systems in Papua New Guinea (PNG) and other low-income countries should sit front and centre for all conservationists interested in socially just, locally owned and controlled pathways to sustainable resource management and biodiversity 
conservation (see especially West \& Aini, this volume). How can the grassroots a) mobilise against their corrupt, patriarchal and predatory elites and b) grasp the importance of the burgeoning threats to their natural resources (principally from transnational capitalists, but also from population pressure) if the mean number of years PNG women spend in school is still less than four (United Nations Development Programme, 2019)? Other branches of the aid community attempt to assist with the education sector in countries such as PNG. However, my point is the ongoing emptiness of the supposed 'development' part of the 'conservation-and-development' paradigm, as prosecuted by the big international NGOs and multilateral agencies, despite well over two decades of sustained critique (Filer, 1994, 2004a, 2004b, 2011; Foale, 2001; Van Helden, 2001; West, 2006).

The overwhelming majority of academics critiquing and protesting against the corrosive impacts of managerialism and the gerrymandered metrics system in the academy are from the humanities and social sciences (Cannizzo \& Osbaldiston, 2019; Ginsberg, 2011; Muller, 2018; Turner, 2019). At JCU, several natural scientists have engaged in this debate; however, most natural, earth and medical scientists are either mute or actively support the system. The main reason for this is that many of those who are advantaged by the system prefer to interpret that advantage as personal virtue (in a striking parallel with George Lakoff's model of American conservatives' contempt for the poor as moral failures; see Lakoff, 2009). This occurs despite the fact that academic jobs in the natural and medical sciences are becoming just as precarious as those in the social sciences and humanities.

Unfortunately, the extent to which neoliberal logics now control the 'market' for academic knowledge production means that the kinds of inquiry that interrogate and critique neoliberalism will inevitably be marginalised in that market. Stephen Turner has observed that:

academic markets are not free markets, in which good ideas compete; they are artificial markets, in which the participants compete for real prizes but under rules that constrain them in ways that transform and deform them. They are, in short, the perfect embodiment of neoliberalism: competition to serve a purpose set by others, not competition in which the ends themselves are subject to competition. (2019, p. 239) 


\section{Conclusion}

Anthropology has opened my eyes to insights into the scientific enterprise and global conservation work that have been transformative, but clearly also burdensome, as epitomised by Arundhati's Roy's famous line: 'the trouble is that once you've seen it, you can't unsee it. And once you've seen it, keeping quiet, saying nothing, becomes as political an act as speaking out' (Roy, 2001, p. 7).

I credit (or perhaps I should blame!) Martha Macintyre, in addition to others in her network, for this change in perspective, which I do not regret, but that has made life and work more complicated for me than I anticipated. While I have not lost any interest in the biology, ecology, evolution and fate of marine life, I can no longer identify as a professional biologist. My adopted discipline of anthropology, however, while enlightening and intellectually empowering, is clearly imperilled by the same neoliberal culture that appears to be advantaging the natural sciences, at least in the institution at which I am currently employed. Having grown up in a colony (the British Solomon Islands), I strongly identify with the powerful perspective on, and critique of, colonialism (both classical and contemporary) that is offered by anthropology and allied disciplines. Colonialism today is manifested in transnational, donor-funded, natural science-dominated conservation work, despite the large canon of (mostly anthropological) work that demonstrates its many problems.

Anthropology, with its persistent focus on the particular, but also an eye on the big picture, will always resist the homogenising demands of the managerialist environmentalism that routinely seeks to find panaceas and 'silver bullets' on a global scale. Anthropologists already view the scientific community's global framing of environmental governance for what it is-just another form of imperialism. Therefore, the challenge for environmental anthropologists is to find ways to convince the scientific community to embrace those powerful anthropological tools of reflexivity and critical political economy to recognise and understand the importance of capitalism and possessive individualism (in addition to population growth) in driving environmental degradation. They must join us in addressing these, rather than routinely scapegoating (albeit in highly politically finessed terms) a homogenised 'Malthusian peasantry', 
whose economic marginality and consequent heavy dependence on natural resources allows them to be constructed as the primary threat to 'globally important' biodiversity.

Some natural scientists 'get' the arguments I have outlined here, so I do not wish this to be a blanket condemnation. But there remains much work to be done to reach those who remain blind to these issues. Anthropologists must also work more collaboratively and collegially to help their younger scholars win grants and break into the system despite the existing handicaps. Anthropologists do not work in teams nearly as much as natural scientists do and would benefit, both intellectually and financially, from doing so. I will continue to reach out to, and collaborate with, my natural science colleagues, despite persistent cultural and structural barriers to redressing the unequal power relationship between us.

\section{Acknowledgements}

I wish to thank Nick Bainton, Debra McDougall, Kalissa Alexeyeff and John Cox for their Herculean efforts to organise this volume. I thank Martha Macintyre for many years of inspiring and mind-expanding collaboration and discussions and for introducing me to so many great minds. Thanks also to Nick Osbaldiston for introducing me to the work of Stephen Turner.

\section{References}

Albert, J. A., Beare, D., Schwarz, A.-M., Albert, S., Warren, R., Teri, J., ... Andrew, N. L. (2014). The contribution of nearshore fish aggregating devices (FADs) to food security and livelihoods in Solomon Islands. PLoS ONE, 9(12), e115386. doi.org/10.1371/journal.pone.0115386

Bainton, N. A. \& Macintyre, M. (2013). 'My Land, My Work': Business development and large-scale mining in Melanesia. In F. McCormack \& K. Barclay (Eds), Engaging with capitalism: Cases from Oceania (Vol. 33) (pp. 139-165). United Kingdom: Emerald Books.

Bainton, N. A. \& Macintyre, M. (2016). Mortuary ritual and mining riches in Island Melanesia. In D. Lipset \& E. K. Silverman (Eds), Mortuary dialogues: Death ritual and the reproduction of moral communities in Pacific Modernities (pp. 110-132). New York, NY: Berghahn. 
Berkes, F. (1999). Sacred ecology: Traditional ecological knowledge and resource management. Philadelphia, PA: Taylor \& Francis.

Berkes, F., Colding, J. \& Folke, C. (2000). Rediscovery of traditional ecological knowledge as adaptive management. Ecological Applications, 10(5), 1251-1262.

Beteille, A. (Ed.). (1969). Social inequality. Harmondsworth, England: Penguin.

Birkeland, C. (1997). Symbiosis, fisheries and economic development on coral reefs. Trends in Ecology \& Evolution, 12(9), 364-367.

Birkeland, C. (2017). Working with, not against, coral-reef fisheries. Coral Reefs, 36(1), 1-11. doi.org/10.1007/s00338-016-1535-8

Bruno, J. F., Cote, I. M. \& Toth, L. T. (2019). Climate change, coral loss and the curious case of the parrotfish paradigm: Why don't marine protected areas improve reef resilience? In C. A. Carlson \& S. J. Giovannoni (Eds), Annual Review of Marine Science (Vol. 11) (pp. 307-334).

Bruno, J. F., Sweatman, H., Precht, W. F., Selig, E. R. \& Schutte, V. G. W. (2009). Assessing evidence of phase shifts from coral to macroalgal dominance on coral reefs. Ecology, 90(6), 1478-1484. doi.org/10.1890/08-1781.1

Bulmer, R. N. H. (1982). Traditional conservation practices in Papua New Guinea. In L. Morauta, J. Pernetta \& W. Heaney (Eds), Traditional conservation in Papua New Guinea: Implications for today (pp. 59-77). Boroko, Papua New Guinea: Institute of Applied Social and Economic Research.

Burton, J. (2007). The anthropology of personal identity: Intellectual property rights issues in Papua New Guinea, West Papua and Australia. The Australian Journal of Anthropology, 18(1), 40-55.

Büscher, B., Fletcher, R., Brockington, D., Sandbrook, C., Adams, W. M., Campbell, L., ... Shanker, K. (2017). Half-earth or whole earth? Radical ideas for conservation, and their implications. Oryx, 51(3), 407-410. doi.org/ $10.1017 /$ S0030605316001228

Cannizzo, F. \& Osbaldiston, N. (Eds). (2019). The social structures of global academia. London, England: Routledge.

Carrier, J. (1981). Ownership of productive resources on Ponam Island, Manus Province. Journal de la Societe des Oceanistes, 37, 205-217.

Carrier, J. (1987). Marine tenure and conservation in Papua New Guinea. In B. J. McCay \& J. M. Acheson (Eds), The question of the commons: The culture and ecology of communal resources (pp. 142-167). Tucson, AZ: University of Arizona Press. 
Chalmers, A. F. (1999). What is this thing called science? (3rd ed.). St Lucia, Qld: University of Queensland Press.

Cinner, J., Marnane, M. J., McClanahan, T. R. \& Almany, G. R. (2006). Periodic closures as adaptive coral reef management in the Indo-Pacific. Ecology and Society, 11(1).

Cinner, J. E., Huchery, C., MacNeil, M. A., Graham, N. A. J., McClanahan, T. R., Maina, J., ... Mouillot, D. (2016). Bright spots among the world's coral reefs. Nature (London), 535, 416-419. doi.org/10.1038/nature18607

Cinner, J. E., McClanahan, T. R., MacNeil, M. A., Graham, N. A. J., Daw, T. M., Mukminin, A., ... Kuange, J. (2012). Comanagement of coral reef socialecological systems. Proceedings of the National Academy of Sciences of the United States of America, 109(14), 5219-5222. doi.org/10.1073/pnas.1121215109

Clifton, J. \& Foale, S. (2017). Extracting ideology from policy: Analysing the social construction of conservation priorities in the Coral Triangle region. Marine Policy, 82, 189-196. doi.org/10.1016/j.marpol.2017.03.018

Cohen, P. \& Foale, S. J. (2013). Sustaining small-scale fisheries with periodic closures. Marine Policy, 37, 278-287. doi.org/10.1016/j.marpol.2012.05.010

Cohen, P., Tapala, S., Rikio, A., Kukiti, E., Sori, F., Hilly, Z., ... Foale, S. (2014). Developing a common understanding of taxonomy for fisheries management in north Vella Lavella, Solomon Islands. SPC Traditional Marine Resource Management and Knowledge Information Bulletin, 33, 3-12.

Conservation International. (2019). Revitalising conservation traditions: The story of Gwala. Retrieved from www.conservation.org/asia-pacific/stories/gwala-rising

Costanza, R., d'Arge, R., de Groot, R., Farber, S., Grasso, M., Hannon, B., ... van den Belt, M. (1997). The value of the world's ecosystem services and natural capital. Nature (London), 387(6630), 253-260.

Cronon, W. (Ed.). (1995). Uncommon ground: Toward reinventing nature. New York, NY: W.W. Norton and Company.

Cronon, W. (1996). The trouble with wilderness: Or, getting back to the wrong nature. Environmental History, 1(1), 7-28.

Curry, G. (1999). Markets, social embeddedness and precapitalist societies: The case of village trade stores in Papua New Guinea. Geoforum, 30, 285-298.

Curry, G. (2005). Doing 'business' in Papua New Guinea: The social embeddedness of small business enterprises. Journal of Small Business and Entrepreneurship, 18(2), 231-246. 
Curry, G., Koczberski, G., Lummani, J., Nailina, R., Peter, E., McNally, G. \& Kuaimba, O. (2015). A bridge too far? The influence of socio-cultural values on the adaptation responses of smallholders to a devastating pest outbreak in cocoa. Global Environmental Change, 35, 1-11. doi.org/10.1016/j.gloenvcha. 2015.07.012

Dey, M. M., Rab, M. A., Paraguas, F. J., Piumsombun, S., Bhatta, R., Alam, M. F. \& Ahmed, M. (2005). Fish consumption and food security: A disaggregated analysis by types of fish and classes of consumers in selected Asian countries. Aquaculture Economics \& Management, 9(1-2), 89-111. doi.org/10.1080/ 13657300590961537

Dowie, M. (2011). Conservation refugees: The hundred-year conflict between global conservation and native peoples. Cambridge, MA: The MIT Press.

Dumont, L. (1970). Homo hierarchicus: The caste system and its implications. Oxford, England: Oxford University Press.

Fabinyi, M. (2018). Environmental fixes and historical trajectories of marine resource use in Southeast Asia. Geoforum, 91, 87-96. doi.org/10.1016/ j.geoforum.2018.02.033

Fabinyi, M., Dressler, W. H. \& Pido, M. (2017). Fish, trade and food security: Moving beyond 'availability' discourse in marine conservation. Human Ecology, 45, 177-188. doi.org/10.1007/s10745-016-9874-1

Fabinyi, M., Evans, L. \& Foale, S. J. (2014). Social-ecological systems, social diversity and power: Insights from anthropology and political ecology. Ecology and Society, 19(4). doi.org/10.5751/ES-07029-190428

Fabinyi, M., Foale, S. \& Macintyre, M. (2013). Managing inequality or managing stocks? An ethnographic perspective on the governance of smallscale fisheries. Fish and Fisheries, 16(3), 471-485.

Fairhead, J. \& Leach, M. (1996). Misreading the African landscape: Society and ecology in a forest-savanna mosaic. Cambridge, England: Cambridge University Press.

Fairhead, J. \& Leach, M. (2000, 5 May). The nature lords. Times Literary Supplement, pp. 3-4.

Fairhead, J., Leach, M. \& Scoones, I. (2012). Green grabbing: A new appropriation of nature? Journal of Peasant Studies, 39(2), 237-261. doi.org/10.1080/ 03066150.2012 .671770 
Ferguson, J. (1990). The anti-politics machine: Development, depoliticization, and bureaucratic power in Lesotho. Minneapolis, MN: University of Minnesota Press.

Filer, C. (1994). The nature of the human threat to Papua New Guinea's biodiversity endowment. In N. Sekhran \& S. Miller (Eds), Papua New Guinea biodiversity country study: The costs and benefits of conserving Papua New Guinea's biodiversity (pp. 187-199). Port Moresby, Papua New Guinea: Papua New Guinea Department of Environment and Conservation, Conservation Resource Centre.

Filer, C. (2004a, March). Hotspots and handouts: Illusions of conservation and development in Papua New Guinea. Paper presented at the Bridging Scales and Epistemologies Conference, Alexandria, Egypt.

Filer, C. (2004b). The knowledge of indigenous desire: Disintegrating conservation and development in Papua New Guinea. In A. Bicker, P. Sillitoe \& J. Pottier (Eds), Development and local knowledge: New approaches to issues in natural resources management, conservation and agriculture (pp. 64-92). London, England: Routledge.

Filer, C. (2011). Interdisciplinary perspectives on historical ecology and environmental policy in Papua New Guinea. Environmental Conservation, 38(2), 256-269. doi.org/10.1017/s0376892910000913

Firth, R. (1965). Primitive Polynesian economy (2nd ed.). London, England: Routledge and Kegan Paul.

Firth, R. (1983). We, the Tikopia: A sociological study of kinship in primitive Polynesia. Stanford, CA: Stanford University Press. (Original work published 1936.)

Foale, S. (1998a). Assessment and management of the trochus fishery at West Nggela, Solomon Islands: An interdisciplinary approach. Ocean and Coastal Management, 40, 187-205.

Foale, S. (1998b). What's in a name? An analysis of the West Nggela (Solomon Islands) fish taxonomy. SPC Traditional Marine Resource Management and Knowledge Information Bulletin, 9, 2-19.

Foale, S. (2001). 'Where's our development?' Landowner aspirations and environmentalist agendas in Western Solomon Islands. The Asia Pacific Journal of Anthropology, 2(2), 44-67.

Foale, S. (2006a). The intersection of scientific and indigenous ecological knowledge in coastal Melanesia: Implications for contemporary marine resource management. International Social Science Journal, 58(187), 129-137. 
Foale, S. (2006b, March, 2004). The scale and epistemology of coral bleaching in Papua New Guinea. Paper presented at the Bridging Scales and Epistemologies, Alexandria.

Foale, S. \& Macintyre, M. A. (2005). Green fantasies: Photographic representations of biodiversity and ecotourism in the Western Pacific. Journal of Political Ecology, 13, 1-22.

Foale, S. \& Manele, B. (2004). Social and political barriers to the use of Marine Protected Areas for conservation and fishery management in Melanesia. Asia Pacific Viewpoint, 45(3), 373-386.

Foale, S. \& Sullivan, N. (2013). Improving livelihoods of coastal artisanal fishing communities in Madang Province, Papua New Guinea, through piloting alternative fishing methods (WWF Project Number WMPO 006). Retrieved from Townsville and Port Moresby: researchonline.jcu.edu.au/31884/

Foale, S., Dyer, M. \& Kinch, J. (2016). The value of tropical biodiversity in rural Melanesia. Valuation Studies, 4(1), 11-39. doi.org/10.3384/VS.20015992.164111

Foale, S., Wini, L. \& Fernandes, L. (2017). The Arnavon community marine conservation area: A review of successes, ongoing challenges and lessons learned. A report to the $M A C B I O$ project. Retrieved from Suva: macbio-pacific.info/ wp-content/uploads/2017/11/Arnavon-Is-Review-digital-091117.pdf

Foale, S., Cohen, P., Januchowski, S., Wenger, A. \& Macintyre, M. (2011). Tenure and taboos: Origins and implications for fisheries in the Pacific. Fish and Fisheries, 12(4), 357-369. doi.org/10.1111/j.1467-2979.2010.00395.x

Foale, S., Adhuri, D., Aliño, P., Allison, E. H., Andrew, N., Cohen, P., ... Weeratunge, N. (2013). Food security and the Coral Triangle Initiative. Marine Policy, 38, 174-183. doi.org/10.1016/j.marpol.2012.05.033

Folke, C., Hahn, T., Olsson, P. \& Norberg, J. (2005). Adaptive governance of social-ecological systems. Annual Review of Environment and Resources, 30, $441-473$.

Folke, C., Carpenter, S., Elmqvist, T., Gunderson, L., Holling, C. S. \& Walker, B. (2002). Resilience and sustainable development: Building adaptive capacity in a world of transformations. Ambio, 31(5), 437-440.

Freire, P. (1973). Education for critical consciousness. New York, NY: The Seabury Press. 
Galaz, V., Crona, B., Dauriach, A., Jouffray, J.-B., Österblom, H. \& Fichtner, J. (2018). Tax havens and global environmental degradation. Nature Ecology \& Evolution, 2, 1352-1357. doi.org/10.1038/s41559-018-0497-3

Ginsberg, B. (2011). The fall of the faculty: The rise of the all-administrative university and why it matters. Oxford, England: Oxford University Press.

Global Financial Integrity. (2015). Financial flows and tax havens: Combining to limit the lives of billions of people. Retrieved from www.gfintegrity.org/report/ financial-flows-and-tax-havens-combining-to-limit-the-lives-of-billions-ofpeople/

Global Financial Integrity. (2017). Illicit financial flows to and from developing countries: 2005-2014. Retrieved from www.gfintegrity.org/wp-content/ uploads/2017/05/GFI-IFF-Report-2017_final.pdf

Gregory, C. A. (1997). Savage money: The anthropology and politics of commodity exchange. Amsterdam, The Netherlands: Harwood.

Gregory, C. A. (1999). South Asian economic models for the Pacific? The case of microfinance. Pacific Economic Bulletin, 14(2), 82-92.

Gregory, C. A. (2015). Gifts and commodities (2nd ed.). Chicago, IL: HAU Books.

Haldane, J. (1963). Review of the truth about death. Journal of Genetics, 58, 463-464.

Henrich, J., Boyd, R., Bowles, S., Camerer, C., Fehr, E., Gintis, H., ... Tracer, D. (2005). 'Economic man' in cross-cultural perspective: Behavioral experiments in 15 small-scale societies. Behavioral and Brain Sciences, 28(6), 795-855.

Hickel, J. (2017). Is global inequality getting better or worse? A critique of the World Bank's convergence narrative. Third World Quarterly, 38(10), 22082222. doi.org/10.1080/01436597.2017.1333414

Hoegh-Guldberg, O. (1999). Climate change, coral bleaching and the future of the world's coral reefs [Review]. Marine \& Freshwater Research, 50(8), 839-866.

Hooper, D. U., Chapin, F. S., Ewel, J. J., Hector, A., Inchausti, P., Lavorel, S., ... Wardle, D. A. (2005). Effects of biodiversity on ecosystem functioning: A consensus of current knowledge. Ecological Monographs, 75(1), 3-35.

Hughes, T. P. (1994). Catastrophes, phase-shifts, and large-scale degradation of a Caribbean coral-reef. Science, 265(5178), 1547-1551.

Hughes, T. P. \& Connell, J. H. (1999). Multiple stressors on coral reefs: A longterm perspective. Limnology \& Oceanography, 44(3), 932-940. 
Hughes, T. P., Bellwood, D. R., Folke, C. S., McCook, L. J. \& Pandolfi, J. M. (2006). No-take areas, herbivory and coral reef resilience. Trends in Ecology \& Evolution, 22(1), 1-3. doi.org/10.1016/j.tree.2006.10.009

Hughes, T. P., Graham, N. A. J., Jackson, J. B. C., Mumby, P. J. \& Steneck, R. S. (2010). Rising to the challenge of sustaining coral reef resilience. Trends in Ecology \& Evolution, 25(11), 633-642. doi.org/10.1016/j.tree.2010.07.011

Hughes, T. P., Baird, A. H., Bellwood, D. R., Card, M., Connolly, S. R., Folke, C., ... Roughgarden, J. (2003). Climate change, human impacts, and the resilience of coral reefs. Science, 301(5635), 929-933.

Hughes, T. P., Barnes, M. L., Bellwood, D. R., Cinner, J. E., Cumming, G. S., Jackson, J. B. C., ... Scheffer, M. (2017). Coral reefs in the Anthropocene. Nature (London), 546(7656), 82-90. doi.org/10.1038/nature22901

Hughes, T. P., Kerry, J. T., Alvarez-Noriega, M., Alvarez-Romero, J. G., Anderson, K. D., Baird, A. H., ... Wilson, S. K. (2017). Global warming and recurrent mass bleaching of corals. Nature (London), 543(7645), 373-377. doi.org/10.1038/nature21707

Hviding, E. (2005). Reef and rainforest: An environmental encyclopedia of Marovo Lagoon, Solomon Islands / Kiladi oro vivineidi ria tingitonga pa idere oro pa goana pa Marovo (2nd ed.). Paris, France: UNESCO-LINKS.

Ingold, T. (1993). Globes and spheres: The topology of environmentalism. In K. Milton (Ed.), Environmentalism: The view from anthropology (pp. 30-43). London, England: Routledge.

Ingold, T. (2000). The perception of the environment: Essays on livelihood, dwelling and skill. London, England: Routledge.

James Cook University. (2019). JCU rated best in the world against UN goal. Retrieved from web.archive.org/web/20190622034704/https://www.jcu. edu.au/news/releases/2019/april/jcu-rated-best-in-the-world-against-un-goal

Johannes, R. E. (1978). Traditional marine conservation methods in Oceania and their demise. Annual Review of Ecology and Systematics, 9, 349-364.

Johannes, R. E., McCloske. L. R., Marsh, J. A., Marshall, N., Maragos, J., Alberts, J., ... Kinzie, R. A. (1972). Metabolism of some coral reef communities: Team study of nutrient and energy flux at Eniwetok. Bioscience, 22(9), 541-543.

Knowlton, N. (1992). Thresholds and multiple stable states in coral reef community dynamics. American Zoologist, 32, 674-682. 
Lakoff, G. (2009). The political mind: A cognitive scientist's guide to your brain and its politics (Vol. 292). New York, NY: Penguin.

Lawrence, P. (1964). Road belong cargo: A study of the cargo movement in the Southern Madang District New Guinea. Melbourne, Vic.: Melbourne University Press.

Lawton, J. H. (1997). The science and non-science of conservation biology. Oikos, 79(1), 3-5. doi.org/10.2307/3546084

Lee, R. B. (1969). Eating Christmas in the Kalahari. Natural History, 78(10), 60-63.

Li, T. M. (2010). To make live or let die? Rural dispossession and the protection of surplus populations. Antipode, 41, 66-93. doi.org/10.1111/j.1467-8330. 2009.00717.x

Lieber, M. D. (1994). More than a living: Fishing and the social order on a Polynesian atoll. Boulder, CO: Westview Press.

Macintyre, M. A. (1998). The persistence of inequality: Women in Papua New Guinea since independence. In L. Zimmer-Tamakoshi (Ed.), Modern Papua New Guinea (pp. 211-231). Kirksville, MO: Thomas Jefferson University Press.

Macintyre, M. A. \& Foale, S. J. (2004). Global imperatives and local desires: Competing economic and environmental interests in Melanesian communities. In V. Lockwood (Ed.), Globalisation and culture change in the Pacific Islands (pp. 149-164). Upper Saddle River, NJ: Pearson Prentice-Hall.

Macintyre, M. A. \& Foale, S. J. (2007). Land and marine tenure, ownership and new forms of entitlement on Lihir: Changing notions of property in the context of a goldmining project. Human Organization, 66(1), 49-59.

Macpherson, C. B. (1962). The political theory of possessive individualism. Oxford, England: Clarendon Press.

Martin, K. (2007). Your own buai you must buy: The ideology of possessive individualism in Papua New Guinea. Anthropological Forum, 17(3), 285-298.

Mead, M. (1956). New lives for old: Cultural transformation: Manus, 1928-1953. New York, NY: Mentor.

Milton, K. (2002). Loving nature: Towards an ecology of emotion. London, England: Routledge.

Milton, K. (Ed.). (1993). Environmentalism: The view from anthropology. London, England; New York, NY: Routledge. 
Mora, C., Aburto-Oropeza, O., Ayala Bocos, A., Ayotte, P. M., Banks, S., Bauman, A. G., ... Zapata, F. A. (2011). Global human footprint on the linkage between biodiversity and ecosystem functioning in reef fishes. PLoS Biol, 9(4), e1000606. doi.org/10.1371/journal.pbio.1000606

Mousseau, F. \& Lau, P. (2015). The great timber heist: The logging industry in Papua New Guinea. Retrieved from www.oaklandinstitute.org/great-timberheist-logging-industry-papua-new-guinea

Muller, J. Z. (2018). The tyranny of metrics. Princeton, NJ: Princeton University Press.

Nussbaum, M. (2011). Creating capabilities: The human development approach. Cambridge, MA: The Bleknap Press of Harvard University Press.

Orlove, B. S. (1980). Ecological anthropology. Annual Review of Anthropology, 9, 235-263.

Ostrom, E. (1990). Governing the commons: The evolution of institutions for collective action. Cambridge, England: Cambridge University Press.

Rappaport, R. A. (1968). Pigs for the ancestors: Ritual ecology of a New Guinea People. New Haven, CT: Yale University Press.

Rappaport, R. A. (1984). Pigs for the ancestors (Rev. ed.). New Haven, CT: Yale University Press. (Original work published 1968.)

Rawlings, G. (2006). Regulating responsively for oversight agencies in the Pacific. State, Society and Governance in Melanesia Targeted Discussion Papers (February), 29.

Rawlings, G. (2011). Relative trust: The Vanuatu tax haven and the management of elite family fortunes. In M. Patterson \& M. Macintyre (Eds), Managing modernity in the Western Pacific (pp. 260-305). St Lucia, Qld: University of Queensland Press.

Redford, K. H. (1991). The ecologically noble savage. Cultural Survival Quarterly, 15(1), 46-48.

Roeger, J., Foale, S. \& Sheaves, M. (2016). When 'fishing down the food chain' results in improved food security: Evidence from a small pelagic fishery in Solomon Islands. Fisheries Research, 174, 250-259. doi.org/10.1016/j.fishres. 2015.10.016

Rose, S. (1997). Lifelines: Biology beyond determinism. Oxford, England: Oxford University Press.

Roy, A. (2001). Power politics. Cambridge, MA: South End Press. 
Russ, G. R. \& Alcala, A. C. (2010). Decadal-scale rebuilding of predator biomass in Philippine marine reserves. Oecologia, 163(4), 1103-1106. doi.org/10.1007/ s00442-010-1692-3

Russ, G. R., Alcala, A. C., Maypa, A. P., Calumpong, H. P. \& White, A. T. (2004). Marine reserve benefits local fisheries. Ecological Applications, 14(2), 597-606.

Russ, G. R., Questel, S. L. A., Rizzari, J. R. \& Alcala, A. C. (2015). The parrotfishcoral relationship: Refuting the ubiquity of a prevailing paradigm. Marine Biology, 162(10), 2029-2045. doi.org/10.1007/s00227-015-2728-3

Sen, A. (1999). Development as freedom. New York, NY: Anchor Books.

Sharman, J. (2008). Power and discourse in policy diffusion: Anti-money laundering in developing states. International Studies Quarterly, 52(3), 635656. doi.org/10.1111/j.1468-2478.2008.00518.x

Sharman, J. (2017). The despot's guide to wealth management: On the international campaign against grand corruption. Ithaca, NY; London, England: Cornell University Press.

Shaxson, N. (2011). Treasure islands: Tax havens and the men who stole the world. London, England: The Bodley Head.

Soule, M. (1985). What is conservation biology. Bioscience, 35(11), 727-734.

Sykes, K. (2007). Interrogating individuals: The theory of possessive individualism in the Western Pacific. Anthropological Forum, 17(3), 213-224.

Times Higher Education. (2018). Average Australian vice-chancellor's pay tips towards A\$1million. Retrieved from www.timeshighereducation.com/news/ average-australian-vice-chancellors-pay-tips-towards-a1-million

Turner, S. (2019). The road from 'vocation': Weber and Veblen on the purposelessness of scholarship. Journal of Classical Sociology, 19(3), 229-253.

United Nations Development Programme. (2019). Human Development Data: Education. Retrieved from hdr.undp.org/en/data\#

Van Fossen, A. (2012). Tax havens and sovereignty in the Pacific Islands. St Lucia, Qld: University of Queensland Press.

Van Helden, F. (2001). Through the thicket: Disentangling the social dynamics of an integrated conservation and development project on mainland Papua New Guinea (Unpublished doctoral thesis). Wageningen University, Wageningen, The Netherlands. 
Vayda, A. P. (1961). Expansion and warfare among swidden agriculturalists. American Anthropologist, 63(21), 346-358.

Vayda, A. P. (1989). Explaining why Marings fought. Journal of Anthropological Research, 45(2), 159-177.

Walker, B. \& Salt, D. (2006). Resilience thinking: Sustaining ecosystems and people in a changing world. Washington DC: Island Press.

Walker, B., Holling, C. S., Carpenter, S. R. \& Kinzig, A. (2004). Resilience, adaptability and transformability in social-ecological systems. Ecology and Society, 9(2), 5. Retrieved from www.ecologyandsociety.org/vol9/iss $2 /$ art5

West, P. (2006). Conservation is our government now: The politics of ecology in Papua New Guinea. Durham, NC: Duke University Press.

West, P., Igoe, J. \& Brockington, D. (2006). Parks and peoples: The social impact of protected areas. Annual Review of Anthropology, 35(1), 251-277. doi.org/ 10.1146/annurev.anthro.35.081705.123308

Wike, R. (2013). The global consensus: Inequality is a major problem. Retrieved from www.pewresearch.org/fact-tank/2013/11/15/the-global-consensus-inequalityis-a-major-problem/

Wilkinson, R. (2005). The impact of inequality: How to make sick societies healthier. London, England: Routledge.

Wilkinson, R. \& Pickett, K. (2009). The spirit level: Why equality is better for everyone. London, England: Penguin.

Worm, B., Barbier, E. B., Beaumont, N., Duffy, J. E., Folke, C., Halpern, B. S., ... Watson, R. (2006). Impacts of biodiversity loss on ocean ecosystem services. Science, 314(5800), 787-790. doi.org/10.1126/science.1132294

Zimmer-Tamakoshi, L. (2012). Troubled masculinities and gender violence in Melanesia. In M. Jolly, C. Stewart \& C. Brewer (Eds), Engendering violence in Papua New Guinea (pp. 73-105). Canberra, ACT: ANU E Press, doi.org/ 10.22459/EVPNG.07.2012 
This text is taken from Unequal Lives: Gender, Race and Class in the Western Pacific, edited by Nicholas A. Bainton, Debra McDougall, Kalissa Alexeyeff and John Cox, published 2021 by ANU Press, The Australian National University, Canberra, Australia.

doi.org/10.22459/UE.2020.03 